\title{
Geographical variation in prevalence of hepatitis $B$ virus DNA in HBsAg negative patients
}

\author{
Y-M D Lo, E S-F Lo, W Z Mehal, M Sampietro, G Fiorelli, G Ronchi, C H Tse, \\ K A Fleming
}

\begin{abstract}
Aims-To study the geographical variation of the prevalence of hepatitis $B$ virus (HBV) DNA in hepatitis B surface antigen (HBsAg) negative subjects.

Methods-A nested polymerase chain reaction (PCR) assay was used to amplify the core region of $\mathrm{HBV}$. The assay was able to detect 10 molecules of a full length HBV plasmid.

Results-When applied to HBsAg negative paraffin wax embedded liver samples from Italy, Hong Kong, and the United Kingdom, a geographical variation in the prevalence of HBV-DNA positivity was noted. Two of 18 (11\%) of Italian samples and $2 / 29(6.9 \%)$ of Hong Kong samples were positive for $\mathrm{HBV}$-DNA while none of the 70 cases from the United Kingdom was positive by nested PCR. Contamination by plasmid DNA was excluded using a novel method based on heteroduplex formation. One HBV-DNA positive case had idiopathic chronic active hepatitis, but the diagnoses in the other three HBV-DNA positive cases did not suggest any aetiological connection between HBV-DNA positivity and liver pathology.
\end{abstract}

Conclusions-HBV-DNA could be detected in the liver tissues of a proportion of HBsAg negative subjects. The prevalence of such cases is related to the endemic rate of a geographical region. The use of HBV PCR on paraffin wax embedded tissues will be valuable for future studies on the molecular epidemiology of HBV.

(f Clin Pathol 1993;46:304-308)

Hepatitis B virus (HBV) infection is a major public health problem, with an estimated carrier population of over 200 million world wide. ${ }^{1}$ Diagnosis used to be based solely on serology, but development of molecular biology has led to the generation of data inconsistent with conventional serology, such as the detection of HBV-DNA in a significant proportion of patients with hepatitis $B$ surface antigen (HBsAg) negative chronic liver disease. ${ }^{23}$ Subsequently, however, other investigators failed to confirm these observations. ${ }^{4-6}$

The development of the polymerase chain reaction $(P C R)^{7}$ has allowed these studies to be repeated using a method with exquisite sensitivity. ${ }^{8}$ The use of the PCR, however, has not resolved the above controversy in that some investigators have succeeded in amplifying HBV-DNA from HBsAg negative individuals $^{9-12}$ while others have failed to do so. ${ }^{13}$ One explanation might be differences in methodologies used by different laboratories, but another reason might be a geographical difference in $\mathrm{HBV}$ virology-the endemic rate.

To address this important question, we benefited from the ability of the PCR to amplify from paraffin wax embedded liver tissues $^{1114}$ which can be transferred easily from country to country. We used a modification of the basic amplification system called nested PCR. This has been shown to be as sensitive as PCR followed by Southern blotting, and yet has the added advantages of being non-isotopic and rapid. ${ }^{15}$ Using this approach, we examined paraffin wax embedded liver tissues from $\mathrm{HBsAg}$ negative subjects from three geographical regions: two high incidence areas (Hong Kong and Italy) and one low incidence area (United Kingdom).

\section{Methods}

HBSAg TESTING

Patients were tested for serum HBsAg by a radioimmunoassay (Abbott Laboratories; Chicago, Illinois) in Milan and enzyme linked immunosorbent assays (ELISAs) in Hong Kong (using an assay produced by Abbott Laboratories) and Oxford (using an assay produced by Biokit). Orcein staining was done for all liver samples; none stained.

\section{PREPARATION OF PARAFFIN WAX EMBEDDED} SECTION FOR PCR

Paraffin wax embedded liver tissues from HBsAg negative subjects were randomly chosen from material collected between 1988 and 1991 stored in the pathological archives of participating centres from three geographical localities. One to $105 \mu \mathrm{m}$ sections were cut from paraffin wax blocks and placed in a $1.5 \mathrm{ml}$ Eppendorf tube. Each tube contained liver tissues with a total volume of $2 \mathrm{~cm}^{2} \times$ $5 \mu \mathrm{m}$. Subsequent processing was essentially as described before. ${ }^{14}$ In brief, the sections were dewaxed in $400 \mu \mathrm{l}$ xylene (Aldrich, HPLC grade), vortexed for 1 minute, and spun for 5 minutes (Microcentaur). The xylene was pipetted off and its residue was removed with $400 \mu \mathrm{l}$ of $95 \%$ ethanol. This was followed by vortexing ( 1 minute) and 


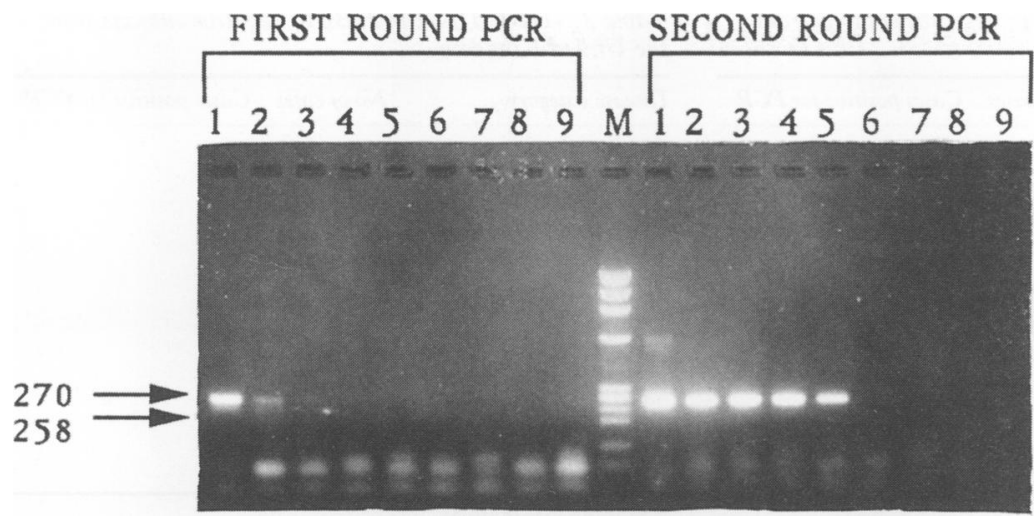

Figure 1 Sensitivity of HBV-PCR assay. Serial dilutions of a plasmid containing a fulllength HBV insert ( $\left.p H B V 130^{\prime 9}\right)$ were amplified by PCR. Results after both the first and the second round are shown. The approximate number of target molecules in the lanes are: lane 1, $10^{7}$; lane 2, $10^{5}$; lane 3, $10^{3}$; lane 4, $10^{2}$; lane 5, 10; lane 6, 1; lane $7,0 \cdot 1$; lane 8, 0.01; lane 9, blank (negative control). $M$ denotes $\varphi \times 174$ DNA digested with HaeIII (marker). 270 and 258 denote the sizes in base pairs of the first and second round PCR products, respectively. spinning (5 minutes). Most of the ethanol was pipetted off and a second $95 \%$ ethanol wash was performed. Most of the ethanol was removed and the rest was removed by incubating in an $80^{\circ} \mathrm{C}$ oven for 10 minutes. One hundred microlitres of digestion buffer ( 50 $\mathrm{mM}$ TRIS, pH8.5, $1 \mathrm{mM}$ EDTA, $0.5 \%$ Tween 20; Sigma) with $200 \mu \mathrm{g} / \mathrm{ml}$ proteinase $\mathrm{K}$ (Boehringer Mannheim) was added to each tube. Digestion with proteinase $\mathrm{K}$ was allowed to proceed overnight at $37^{\circ} \mathrm{C}$.

After digestion the tube was spun briefly and heated to $94^{\circ} \mathrm{C}$ for 20 minutes to inactivate the proteinase $K$. Ten microlitres were then used for PCR assay.

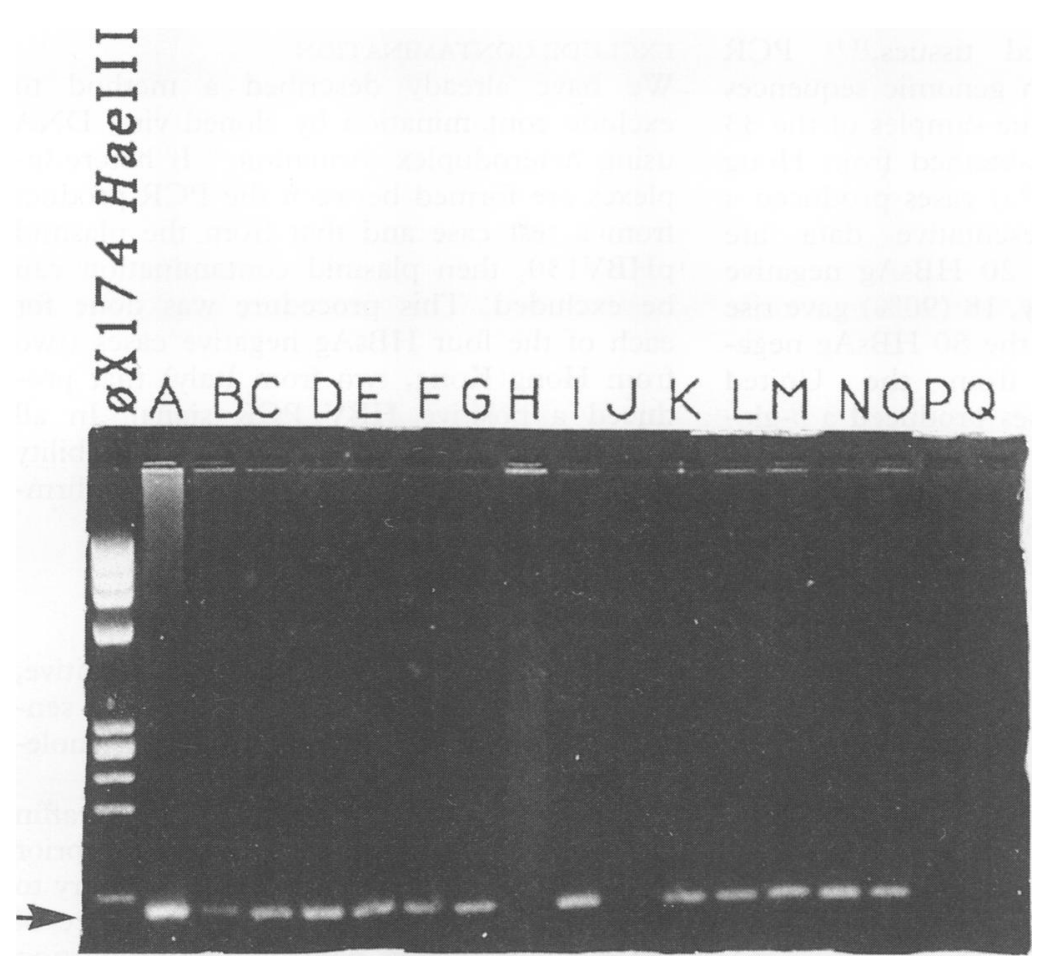

Figure 2 Amplification of $\beta$-globin sequences from paraffin wax embedded tissues. Lanes $A$ to $P$ are results of $P C R$ amplification of a $\beta$-globin genomic sequence from a series of formalin fixed, paraffin wax embedded liver biopsies from Hong Kong. Failed amplifications are seen in lanes $H, \mathcal{F}$, and $P$. Lane $Q$ is the negative control (blank). Arrow indicates position of the 110 base pair $\beta$-globin PCR product.
POLYMERASE CHAIN REACTION

The PCR was carried out as described. ${ }^{7}$ Reagents were obtained from a GeneAmp DNA Amplification Reagent Kit (PerkinElmer Cetus). PCR was performed in $50 \mu \mathrm{l}$ reactions with 1.25 units of $T a q$ polymerase (Perkin-Elmer Cetus). DNA amplification was carried out using a Biometra Trio Thermoblock. After an initial denaturation step at $95^{\circ} \mathrm{C}$ for 3 minutes subsequent cycling profile was $94^{\circ} \mathrm{C}$ for 1 minute, $55^{\circ} \mathrm{C}$ for 1 minute, and $72^{\circ} \mathrm{C}$ for 1 minute.

Each sample was first amplified using primers PC03 and $\mathrm{PC} 04^{16}$ specific to the $\beta$ globin gene. Forty cycles of PCR were carried out. Only samples producing a positive $\beta$-globin signal were amplified using HBV primers. The nested PCR system ${ }^{15}$ for the core gene of HBV consisted of 40 cycles of first round PCR using primers 1763 and 2032R (PCR product size: 270 base pairs). Two microlitres of the first round PCR products were then reamplified for 25 cycles using primers $1778 \mathrm{E}$ and 2017RB (PCR product size: 258 base pairs).

Primer sequences are listed below:

PC03: 5'ACACAACTGTGTTCACTAGC $3^{\prime}$

PC04: 5'CAACTTCATCCACGTTCACC 3' 1763: 5'GCTTTGGGGCATGGACATTGACCCGTATAA 3'

2032R: 5'CTGACTACTAATTCCCTGGATGCTGGGTCT 3'

1778E: 5'GACGAATTCCATTGACCCGTATAAAGAATT 3'

2017RB: 5'ATGGGATCCCTGGATGCTGGGTCTTCCAAA 3'

ANALYSIS OF AMPLIFIED DNA

Ten to $20 \mu \mathrm{l}$ of the PCR products were run on a $1.5 \%$ agarose gel. DNA was visualised by ultraviolet fluorescence after staining with ethidium bromide.

\section{PREVENTION AND DETECTION OF}

CONTAMINATION

To minimise the risk of contamination, all of the previously published guidelines were observed. ${ }^{1718}$ As a plasmid containing a fulllength $\mathrm{HBV}$ insert ( $\mathrm{pHBV} 130)^{19}$ was used as a positive control in the PCR experiments, contamination by PCR products from the plasmid was potentially possible. Exclusion of plasmid PCR products as the source of contamination was carried out using the recently described heteroduplex method. ${ }^{20}$ Thus all PCR products from test samples were mixed with an equimolar amount of the PCR product from pHBV130, denatured at $94^{\circ} \mathrm{C}$ for 5 minutes and reannealed at $65^{\circ} \mathrm{C}$ for $5 \mathrm{~min}$ utes. The mixtures were cooled to $4^{\circ} \mathrm{C}$ for 10 minutes before being run on a $10 \%$ nondenaturing polyacrylamide gel in TBE $(0.089$ $M$ TRIS, $0.089 \mathrm{M}$ boric acid, $2 \mathrm{mM}$ EDTA, pH8.0). In the presence of sequence differences between the PCR products from the test samples and that from the plasmid, heteroduplexes would be seen, and thus contamination by plasmid derived DNA could be excluded. Conversely, if no heteroduplexes 
Table 1 HBV DNA in HBsAg negative subjects from Hong Kong

\begin{tabular}{lll}
\hline Disease category & No of cases & Cases positive for PCR \\
\hline $\begin{array}{c}\text { Hepatocellular } \\
\text { carcinoma }\end{array}$ & 3 & 0 \\
$\begin{array}{c}\text { Chronic active } \\
\text { hepatitis } \\
\text { (idiopathic) }\end{array}$ & 3 & 0 \\
$\begin{array}{c}\text { Acute hepatitis } \\
\text { (idiopathic) }\end{array}$ & 4 & 0 \\
$\begin{array}{c}\text { Biliary disease } \\
\text { Cryptogenic }\end{array}$ & 5 & 0 \\
$\begin{array}{c}\text { cirrhosis } \\
\text { Alcoholic liver } \\
\text { disease }\end{array}$ & 1 & 0 \\
$\begin{array}{c}\text { Fulminant hepatitis } \\
\text { Liver tumours } \\
\text { (non-hepatocellular } \\
\text { carcinoma, including } \\
\text { secondaries) }\end{array}$ & 1 & 0 \\
Miscellaneous & 3 & $1^{\star}$ \\
\hline
\end{tabular}

* Secondary adenocarcinoma, anti-HBs negative, anti-HBc not tested.

$\S$ Non-specific changes, anti-HBs negative, anti-HBc not tested.

were observed, contamination tracing back to pHBV130 could not be excluded.

\section{Results}

SENSITIVITY OF HBV PCR SYSTEM

To determine the sensitivity of the nested HBV PCR system, serial dilutions of a plasmid containing a full-length $\mathrm{HBV}$ insert (pHBV130) ${ }^{19}$ were made in water. After 40 cycles of first round PCR, a signal was visible in an ethidium stained gel for $10^{5}$ molecules (fig 1). After 25 cycles of second round PCR the detection limit was extended to the equivalent of 10 molecules (fig 1). This sensitivity was similar to that previously reported by Kaneko et al. ${ }^{15}$

AMPLIFICATION OF $\beta$-GLOBIN SEQUENCES FROM WAX EMBEDDED TISSUES

Due to the existence of inhibitors in certain paraffin wax embedded tissues, ${ }^{11} 14$ PCR amplification of $\beta$-globin genomic sequences was attempted in all tissue samples of the 33 HBsAg negative cases obtained from Hong Kong. Twenty nine $(88 \%)$ cases produced a $\beta$-globin signal. Representative data are shown in fig 2 . Of the $20 \mathrm{HBsAg}$ negative cases obtained from Italy, $18(90 \%)$ gave rise to a $\beta$-globin signal. Of the $80 \mathrm{HBsAg}$ negative cases obtained from the United Kingdom, $70(88 \%)$ cases produced a $\beta$-globin signal. The proportion of cases giving successful $\beta$-globin amplification was consistent with our earlier observations. ${ }^{21}$ These cases were then chosen for amplification using the nested HBV PCR system.

Table $2 H B V-D N A$ in $H B s A g$ negative subjects from Italy

\begin{tabular}{lll}
\hline Disease category & No of cases & Cases positive for PCR \\
\hline $\begin{array}{l}\text { Genetic disorders\# } \\
\text { Bilary disease }\end{array}$ & 4 & 0 \\
$\begin{array}{l}\text { Alcoholic liver } \\
\text { disease }\end{array}$ & 1 & 0 \\
$\begin{array}{l}\text { Chronic active hepatitis } \\
\text { (idiopathic) }\end{array}$ & 8 & 0 \\
$\begin{array}{l}\text { Post-necrotic cirrhosis } \\
\text { Miscellaneous }\end{array}$ & 1 & 1 \\
\hline
\end{tabular}

\# Haemochromatosis and Wilson's disease.

* Anti-HBs negative, anti-HBc negative.

Porphyria cutanea tarda, anti-HBs negative, anti-HB negative.
Table $3 H B V-D N A$ in $H B s A g$ negative subjects from the United Kingdom

\begin{tabular}{|c|c|c|}
\hline Disease category & No of cases & Cases positive for $P C R$ \\
\hline Alcoholic liver disease & 7 & 0 \\
\hline $\begin{array}{l}\text { Chronic active hepatitis } \\
\text { (idiopathic) }\end{array}$ & 5 & 0 \\
\hline Biliary disease & 28 & 0 \\
\hline $\begin{array}{l}\text { Cryptogenic } \\
\text { cirrhosis }\end{array}$ & 3 & 0 \\
\hline $\begin{array}{l}\text { Acute hepatitis } \\
\text { (idiopathic) }\end{array}$ & 5 & 0 \\
\hline $\begin{array}{l}\text { Liver tumours } \\
\text { (non-hepatocellular } \\
\text { carcinoma, including } \\
\text { secondaries) }\end{array}$ & 12 & 0 \\
\hline Genetic disorders\# & 1 & 0 \\
\hline Miscellaneous & 9 & 0 \\
\hline
\end{tabular}

\# Haemochromatosis.

AMPLIFICATION OF HBV SEQUENCES USING

NESTED PCR

Twenty nine, 18, and 70 cases from Hong Kong, Italy, and the United Kingdom, respectively, were analysed using nested HBV PCR. These were cases which gave a positive $\beta$-globin PCR signal and all were from HBsAg negative subjects. The results are summarised in tables $1-3$. In all cases the positive HBV-PCR signal was only visible after the second round PCR. Representative data are shown in fig 3. Two of $18(11 \%)$ and $2 / 29(6.9 \%)$ of HBsAg negative cases from Italy and Hong Kong, respectively, were positive by nested PCR. A total of 47 cases $(8.5 \%)$ tested in the high incidence areas were therefore positive in the HBV PCR assay. In the low incidence area (United Kingdom) studied, none of the 70 cases studied was positive by nested PCR. These results were significant $\left(p<0.05 ; \chi^{2}=3.86\right.$; degree of freedom = 1).

HETERODUPLEX FORMATION AS A MEANS TO EXCLUDE CONTAMINATION

We have already described a method to exclude contamination by cloned viral DNA using heteroduplex formation. ${ }^{20}$ If heteroduplexes are formed between the PCR product from a test case and that from the plasmid pHBV130, then plasmid contamination can be excluded. This procedure was done for each of the four HBsAg negative cases (two from Hong Kong, two from Italy) that produced a positive HBV PCR signal. In all cases heteroduplexes with different mobility patterns were observed (fig 4), thus confirming the validity of the results.

\section{Discussion}

The nested PCR system used was sensitive, rapid, and completely non-isotopic. The sensitivity of the method was such that 10 molecules of HBV DNA could be detected.

The presence of PCR inhibitors in paraffin wax embedded tissues required the prior exclusion of samples which were refractory to PCR. This demonstrated the importance of the $\beta$-globin positive control. The proportion of samples which were refractory to PCR ranged from $10-12 \%$ and was consistent with previous observations. ${ }^{21}$

Our data confirmed previous observations 


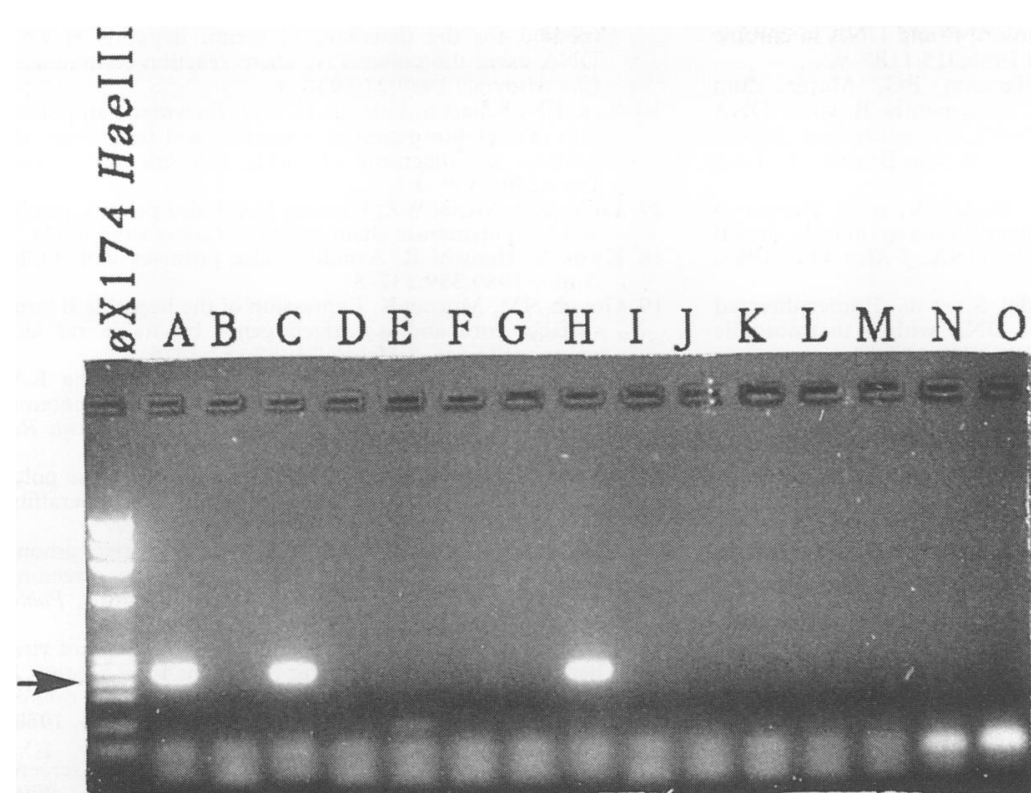

Figure 3 Amplification of $H B V$ sequences from $\mathrm{HBs} A g$ negative subjects using nested $P C R$. Results following the second round PCR are shown. Lane $A$ denotes the positive control $\left(p H B V 130^{19}\right)$. Lanes $B$ to $N$ show results on a series of liver biopsy specimens from Hong Kong. Lanes $C$ and $H$ show positive $H B V$ amplifications. Lane $O$ is the negative control (blank). The low molecular weight bands in lanes $N$ and $O$ represent primer dimers. Arrow indicates the position of the 258 base pair second round PCR product.

that HBV DNA could be detected in a proportion of $\mathrm{HBsAg}$ negative subjects. ${ }^{9-12}$ Furthermore, the proportion of such cases seems to be related to the endemic rate of $\mathrm{HBV}$ infection in a geographical region. Thus in high incidence areas such as Milan and Hong Kong, with a carrier rate of $3.5 \%{ }^{22}$ and $9 \cdot 6 \%,{ }^{23}$ respectively, the percentages of $\mathrm{HBV}$ DNA positive cases were $11 \%$ and $6.9 \%$, respectively. The HBsAg positive carrier rate in London has been estimated at $0.5 \%{ }^{24}$ and the carrier rate in Oxford is likely to be much lower. We have not been able to detect any HBV DNA in any of the 70 cases from the United Kingdom. It should be noted that our figures for HBV DNA positivity in Milan and Hong Kong should be regarded as gross estimates because the numbers involved are too small to provide a precise figure on the prevalence. Nevertheless, the difference in HBV

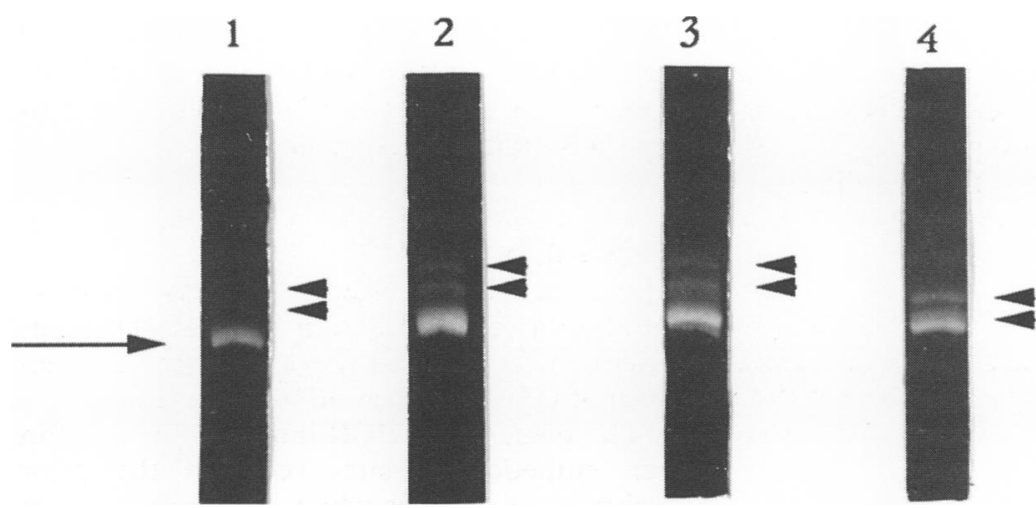

Figure 4 Heteroduplex analysis for excluding contamination. Lane 1, PCR product from a liver biopsy specimen from Hong Kong (secondary adenocarcinoma); lane 2, PCR product from a liver biopsy specimen from Hong Kong (non-specific changes); lane 3 , $P C R$ product from a liver biopsy specimen from Italy (chronic active hepatitis); lane 4, PCR product from a liver biopsy specimen from Italy (porphyria cutanea tarda). Arrow indicates position of homoduplex of the 258 base pair second round PCR product. Arrowheads indicate positions of heteroduplexes. Note mobility differences among heteroduplexes from different cases.
DNA prevalence between the high and low incidence areas is highly significant.

The commercially available tests for HBsAg used in this study were radioimmunoassay or ELISA based and these assays had a sensitivity of $<0.5 \mathrm{ng} / \mathrm{ml} .{ }^{25}$ In a direct comparison between the three assays, the ELISA made by Biokit was not as sensitive as the radioimmunoassay and ELISA manufactured by Abbott Laboratories (Dr J Kurtz, John Radcliffe Hospital, personal communication). The assay used in Oxford would therefore bias our results in that we may have missed some cases with low concentrations of HBsAg. Hence the observation that none of the Oxford cases was positive by PCR is highly significant.

Our data, however, did not provide conclusive evidence of an aetiological link between HBV DNA positivity and the liver pathology seen. Interestingly, one Italian case diagnosed as having idiopathic chronic active hepatitis was shown to have HBV DNA by nested PCR. HBV could potentially have been the cause of liver pathology in this case. However, for the other three cases (porphyria cutanea tarda, secondary adenocarcinoma, and non-specific changes), the role of $\mathrm{HBV}$ was less clear. Nevertheless, these data show that $\mathrm{HBV}$ is present in a proportion of HBsAg negative subjects which may have public health implications in high incidence areas.

Some investigators have used multiple primer sets for $\mathrm{HBV}$ detection by $\mathrm{PCR}^{11}$; others have used only one set of primers. ${ }^{12}$ The use of multiple primer sets might increase the detection rate of HBV-DNA in our samples, but we do not think that this will alter our basic conclusions. Our belief is based on the relatively large sample size of our study (117 cases in total) and the fact that the primer combination we used has been used before to detect HBV DNA in HBsAg negative subjects. ${ }^{11} 12$

Finally, the heteroduplex method $^{20}$ we used to exclude contamination due to cloned viral DNA has been confirmed to be reliable and rapid. The differences in mobility of heteroduplexes from different cases shown in fig 4 were consistent with a previous report showing a $2-15 \%$ difference in nucleotide sequence in the core gene amplified from different $\mathrm{HBV}$ isolates. ${ }^{12}$ We envisage that this method could be widely applied in many virological laboratories. Furthermore, the method could potentially be modified for typing viruses. We thank the Wellcome Trust and Foulkes' Foundation
Fellowship for financial support. We also thank Dr Eric Yap Foundation and Dr J Kurtz for helpful discussion.

1 Zuckerman AJ, Sun T-T, Linsell A, Stjerrsward J. Prevention of primary liver cancer. Report on a meeting of a WHO Scientific Group. Lancet 1983;i:463-5.

2 Brech $C$. DNA in patients with chronic liver disease and negative tests for hepatitis B surface antigen. N Engl f Med 1985;
312:270-6.

Figus A, Blum HE, Vyas GN, et al. Hepatitis B viral nucleotide sequences in non-A, non-B, or hepatitis virus-related chronic liver disease. Hepatology 1984;4: 364-8. 
4 Yokosuka $\mathrm{O}$, Omata $\mathrm{M}$, Imazeki $\mathrm{F}$, Ito $\mathrm{Y}$, Okuda $\mathrm{K}$. Hepatitis B virus RNA transcripts and DNA in chronic liver disease. N Engl f Med 1986;315:1 187-92.

5 Slusarczyk J, Hess G, Hansson BG, Meyer Zum Buschenfelde $\mathrm{K}-\mathrm{H}$. Lack of hepatitis B virus DNA sequence in sera from patients with acute and chronic liver disease diagnosed as non-A, non-B hepatitis. Liver 1986;6:337-40.

6 Fowler MJF, Monjardino J, Weller IV, et al. Failure to detect nucleic acid homology between non-A, non-B viruses and hepatitis B virus DNA. I Med Virol 1983, 12:205-13.

7 Saiki RK, Gelfand D, Stoffel S, et al. Primer-directed enzymatic amplification of DNA with a thermostable DNA polymerase. Science 1988;239:487-91.

8 Brechot C. Polymerase chain reaction: a new tool for the study of viral infections in hepatology. F Hepatol 1990: 11:124-9.

9 Thiers V, Nakajima E, Kremsdorf D, et al. Transmission of hepatitis B from hepatitis B seronegative subjects. Lancet 1988;ii:1273-6.

10 Liang TJ, Blum HE, Wands JR. Characterization and biological properties of a hepatitis B virus isolated from patient without hepatitis B virus serologic markers. Hepatology 1990;12:204-12.

11 Lampertico P, Malter JS, Colombo M, Gerber MA Detection of hepatitis $B$ virus DNA in formalin-fixed paraffin-embedded liver tissue by the polymerase chain reaction. Am F Pathol 1990;137:253-8.

12 Kaneko S, Miller RH, Feinstone SM, et al. Detection of serum hepatitis $B$ virus DNA in patients with chronic hepatitis using the polymerase chain reaction assay. Proc Natl Acad Sci USA 1989;86:312-6.

13 Yokosuka O, Omata $M$, Hosoda $K$, Tada $M$, Ehata $T$ Ohto $M$. Detection and direct sequencing of hepatitis $B$ virus genome by DNA amplification method. 1991;100:175-81.

14 Lo Y-MD, Mehal WZ, Fleming KA. In vitro amplification of hepatitis B virus sequences from liver tumour DNA and from paraffin wax embedded tissues using the poly merase chain reaction. $\mathcal{f}$ Clin Pathol 1989;42:840-6.
15 Kaneko S, Feinstone SM, Miller RH. Rapid and sensitive method for the detection of serum hepatitis B virus DNA using the polymerase chain reaction technique. $f$ DNA using the polymerase ch

16 Saiki RK, Scharf S, Faloona F, et al. Enzymatic amplification of $\beta$-globin genomic sequences and restriction site analysis for diagnosis of sickle cell anemia. Science 1985;230:1350-4.

17 Lo Y-MD, Mehal WZ, Fleming KA. False-positive results and the polymerase chain reaction. Lancet 1988;ii:679.

18 Kwok S, Higuchi R. Avoiding false positives with PCR Nature 1989;339:237-8.

19 Gough NM, Murray K. Expression of the hepatitis B virus surface, core and $e$ antigen genes by stable rat and mouse cell lines. F Mol Biol 1982;162:43-6.

20 Lo Y-MD, Lo ES-F, Patel P, Tse CH, Fleming KA Heteroduplex formation as a means to exclude contamination in virus detection using PCR. Nucleic Acids Res nation in virus
1991;19:6653.

21 An SF, Fleming KA. Removal of inhibitor(s) of the polymerase chain reaction from formalin-fixed, paraffinembedded tissue. 7 Clin Pathol 1991;44:924-7.

22 Stroffolini T, Pascuini P, Mele A. HBsAg carriers amon pregnant women in Italy: results from the screening during a vaccination campaign against hepatitis. Public Health 1988;102:329-33.

23 Yeoh EK, Chang WK, Kwan JPW. Epidemiology of viral hepatitis B infection in Hong Kong. In: Viral hepatitis $B$ infection in the Western Pacific Region: vaccine and control. 1st edn. Singapore: World Scientific Publications, 1984: 33-41.

24 Brook MG, Lever AML, Kelly D, et al. Antenatal screening for hepatitis B is medically and economically effective in the prevention of vertical transmission: three years experience in a London hospital. $Q \mathcal{F} \mathrm{Med} 1989$ 264:313-7.

25 U.S. Department of Health and Human Services. Public Health Service Inter-Agency guidelines for screening donors of blood, plasma, organs, tissues, and semen for evidence of hepatitis B and hepatitis C. Morbid Mortal Weekly Rep 1991;40:1-17. 